\begin{tabular}{|c|c|c|c|c|c|c|}
\hline \multirow{4}{*}{ Impact Factor: } & ISRA (India) & $=3.117$ & SIS (USA) & $=0.912$ & ICV (Poland) & $=6.630$ \\
\hline & ISI (Dubai, UAE & $=0.829$ & РИНЦ (Russia) & $=0.156$ & PIF (India) & $=1.940$ \\
\hline & GIF (Australia) & $=0.564$ & ESJI (KZ) & $=5.015$ & IBI (India) & $=4.260$ \\
\hline & JIF & $=1500$ & & & & \\
\hline
\end{tabular}

SOI: $\underline{1.1 / \text { TAS }}$ DOI: $10.15863 /$ TAS

International Scientific Journal Theoretical \& Applied Science

p-ISSN: 2308-4944 (print) e-ISSN: 2409-0085 (online)

Year: $2018 \quad$ Issue: 12 Volume: 68

Published: 27.12.2018 http://T-Science.org

SECTION 33: Advertising technologies.

Creative. Innovations

UDC 685.34:335.74
QR - Issue
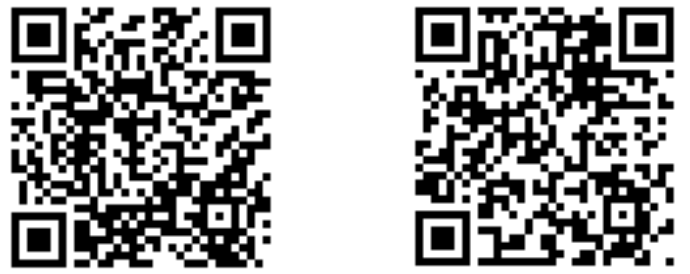

D. O. Borduch

Institute of Service and Entrepreneurship (branch) of DSTU, ( Shakhty, Russia)

A.A. Blagorodov

Institute of Service and Entrepreneurship (branch) of DSTU, ( Shakhty, Russia)

V.T. Prokhorov

Doctor of technical sciences, professor, professor of the department "Designing, technology and design", ISOP (f) DGTU, g. Shakhty

N.V. Tihonova

Doctor of technical sciences, professor, professor of the department «Designing clothing and footwear», Research technological University

(Kazan, Tatarstan)

\title{
ABOUT FINDING EFFECTIVE SOLUTIONS FOR IMPLEMENTATION MADE BY THE ENTERPRISES OF THE REGIONS OF THE SFD AND SKFO OF IMPORT-SUBSTITUTING PRODUCTS
}

Abstract: In the message 1 for analysis of a system of indicators for assessing the competitive potential of the enterprise and the importance of consumer properties of products, the authors propose to use a direct estimation method that allowed to obtain a generalized estimation of competitiveness, which on the one hand allows to show the degree of satisfaction with the product, and the degree of use of the competitive potential of the enterprise.

Key words: assessment of enterprise competitiveness and product innovation processes, profit, profitability, import substitution, assortment policy, competitive potential, target segment, the importance of consumer properties

Language: English

Citation: Borduch, D. O., Blagorodov, A. A., Prokhorov, V. T., \& Tihonova, N. V. (2018). About finding effective solutions for implementation made by the enterprises of the regions of the sfd and skfo of importsubstituting products. ISJ Theoretical \& Applied Science, 12 (68), 263-270.

Soi: http://s-o-i.org/1.1/TAS-12-68-38 Doi: crossef https://dx.doi.org/10.15863/TAS.2018.12.68.38

\section{Introduction}

In the division of the attributes of quality into "primary" and "secondary" there was a rational beginning associated with the specificity of the "second nature" - things transformed from the natural state by human labor. "Primary" qualities of the product or its raw materials are conditioned by natural reality and fully independent of man. "Secondary" signs, on the contrary, are dependent on human labor. It is their work that reveals or creates, and therefore the quality of the objects transformed by labor must be determined with a human estimate.
The inclusion of man as a factor in the production of the quality of the goods enhances the influence of the subject of labor on the quality of production and the quality of the produced goods. In connection with this, the workload on the management process is increasing.

Management is subject to the task of sustainable receipt of a quality product. As in any task, it is necessary to:

- clearly define what is "quality" ?;

- Understand what is specific to the quality of the product?; 


\begin{tabular}{|c|c|c|c|c|c|c|}
\hline \multirow{4}{*}{ Impact Factor: } & ISRA (India) & $=3.117$ & SIS (USA) & $=0.912$ & ICV (Poland) & $=6.630$ \\
\hline & ISI (Dubai, UAI & $=0.829$ & РИНЦ (Russia) & $=0.156$ & PIF (India) & $=1.940$ \\
\hline & GIF (Australia) & $=0.564$ & ESJI (KZ) & $=5.015$ & IBI (India) & $=4.260$ \\
\hline & JIF & $=1.500$ & SJIF (Morocco) & $=5.667$ & & \\
\hline
\end{tabular}

- to understand how the "quality" of commodity production and its mass character are related, to trace the mechanism of interaction of qualitative changes with quantitative ones;

- To reveal (disclose)l the systemic position of the problem of mass production quality in the context of a developing economy.

Only if we received answers to the above questions, we would be able to productively study the problem: "How realistic is our desire to give the mass manufacturer the need for the quality of the commodity result," in other words, "is it possible to sufficient to motivate the receipt of a quality product from within mass production?". Unfortunately, quality management is carried out by introducing into the production of ideas developed not in it, but in a "pure" management theory.

\section{Main part}

Such a mechanism of quality management raises the importance of scientific analysis, determining the self-movement of production to quality the role of subsidiary, experimental farming. A retrospective view of the history of understanding how to manage the quality of production in general terms demonstrates clearly that this story is very similar to the movement of thought on the principle of "trial and error." Each following "theory" after S. Colt (1870s) - G. Lalande, G. Ford, A. Fayol, M. Weber, F. Taylor, V. Shuhert, E. Deming, I. Ishikawa, I. Jurana, F. Crosby, A. Feigenbaum invariably resembled the way out of the impasse in which her predecessor started, until in the end they replaced the key concept of SK for QMS - "Quality Management System." [1] Comparison of QMS with UK allows us to consider the trend of the movement - the desire, developing a new approach to quality management, to overcome the narrow technological view on quality as a certain standard limited by the production process outside the conditions of consumption.

The interpretation of the quality of goods developed under the influence of economic rationality does not reflect the socio-cultural status of the commodity, at least of the consumer row. Qualitative characteristics of the goods intended for mass consumption, it is expedient to search at the intersection of production, economic and sociocultural advantages. And it is desirable that the goods not only meet the existing needs, but also stimulate their cultural development, served as an instrument for the development of the consumer's personality. Human capital participates in the creation of the product of production, and production is called upon to promote the perfection of the individual. There is no other way to overcome alienation in conditions of the absoluteization of private property and its size disproportionate to labor. Only giving the labor of creativity and the corresponding reward to creativity can be "removed", expressed in terms of Hegelians philosophy, the tension of alienation. The quality of goods in a broad sense can be regarded as a factor of social progress and as a test of socio-cultural achievements of social development.

In the definition of quality, the most common shortcoming is the lack of systematicity. Quality is defined as a set of essential properties. The usual method of these selecting is the method of pyramidal arrangement of the properties of the object. At the base remain important, but not defining, and as you climb to the top, a hierarchy of the remaining properties is formed. At the top, we get the sum of the main properties, which are included in the definition of the quality of the object. G. Hegel at one time cleverly determined the quality from the opposite: "quality is that, losing that, the object ceases to be itself." [2]

Following the example of the great thinker, we define "shoes" as "clothes for the feet". How true will this definition be? For shoes, probably yes. For the quality of shoes is unlikely. If you deprive the shoes of the ability to be "the clothes of the feet," then it really will not be shoes. If you keep your shoes only the ability inherent in it, then the required quality of the product will be vague. "Footwear" can be dangerous because of the toxicity of the material, means of attachment, uncomfortable for the movement of the structure. The formally formulated requirement for an object does not coincide with the quality of the subject. It is significant as a prerequisite for the qualitative certainty of the product. To determine the quality of goods, one must go from its functional designation. The functional purpose should be considered as a state of relations of a formally defining object with the specificity of the operation of the object, its commodity purpose, concluded in the consumer value of the goods.

Legs for which clothes are made in the form of shoes, represent part of a living organism. These are not pads and not limbs of the corpse, also intended for certain clothing. Clothes for the feet will not be shoes until they have sufficient evidence of its safety - hygienic, ergonomic, industrial, economic household. Quality is not a collection of essential properties of a commodity, it is their system, the system-forming feature of which really is the ability to perform some formally most significant function. It is also laid in the basis of determining the quality of goods "growing" then the system itself, as grown from a random grains of pearls in the sink or the periodic system of chemical elements from atomic weight.

G. Hegel was right in his definition of quality, to start always better with what is "in sight", then to increase the definition. Around the nucleus of the atom there is an electron shell and together they give 


\begin{tabular}{|c|c|c|c|c|c|c|}
\hline \multirow{4}{*}{ Impact Factor: } & ISRA (India) & $=3.117$ & SIS (USA) & $=0.912$ & ICV (Poland) & $=6.630$ \\
\hline & ISI (Dubai, UAI & $=0.829$ & РИНЦ (Russia) & $=0.156$ & PIF (India) & $=1.940$ \\
\hline & GIF (Australia) & $=0.564$ & ESJI (KZ) & $=5.015$ & IBI (India) & $=4.260$ \\
\hline & JIF & $=1.500$ & SJIF (Morocco) & $=5.667$ & & \\
\hline
\end{tabular}

the definition of an atom. In the definition, we lay down quality, revealing it later in the aggregate of concretizing properties. [3]

From a philosophical point of view, the quality of an object, reflecting the diversity of the world, reproduces in itself this objectively existing objective difference. The quality of the goods, especially mass direct human consumption, requires additional clarification, related to the manufacturer's responsibility for the safety of the use of the product. The quality of goods "consumer goods" is more complex structured. Its definition includes the system location of the main competencies of technical and humanitarian significance.

Shoes of their quality, by definition, should ensure the interaction of two fundamental competencies - safety and comfort in operation. The aesthetic properties of footwear are subordinated to them and packed in them. With their help, the producer "attracts" the consumer like plant flowers calling for insects, which produce pollination through consumption.

The cultural evaluation of the product is mistakenly simplified to the level of aesthetic value of the products. The cultural status of the product synthesizes in itself and the culture of performance, and the culture of consciousness of the manufacturer, deciding which materials to use, in whose interests it is to operate - the profitability of production or the needs of the consumer trusting the manufacturer. Ascending, we can easily rise to the very top - the culture of social consciousness. In some countries they do not steal, they consider deception to be baseness, and in others everything is built on these vices, they are legalized, for they have grown into the national mentality.

The substitution of a philosophical understanding of the quality of a commodity with an economic one is natural for an economy aimed primarily at making a profit, increasing capital in private interests. The economic dominant in the quality characteristic has an ideological basis. In the same context, one should also consider the desire to separate the economy from socio-cultural development. The idea that the economic movement should be absolutely independent of political supervision and humanitarian functions, all noneconomic is ensured by taxes from the economy, is gaining strength, and most importantly it is supported by power. Attempts to oppose this logic, the common sense of social development as the progress of the individual and interpersonal relations within the framework of the social organization of the historical process are ineffective. They are given the role of local public opinion, which has never been particularly solidarity. The philosophical system analysis of the quality and defects of its interpretation remains the lot of professional reflection.
It would seem that we have a purely theoretical problem: what to call the real quality of the goods and how does the system of qualitative properties look like in the characteristics of the goods? In reality, with practical application, it grows into an ideological problem: what is permissible to see the quality of a commodity in the contemporary concrete historical circumstances of social cultural development.

Simplification of the understanding of the quality of the goods by reducing it to its properties that ensure the profitability of production makes production, and not the consumer, a system-forming factor for obtaining the "quality" of the goods, which contradicts the quality of the developed economy of the "postindustrial", "new industrial" and even "industrial" society. At the dawn of humanity, the consumer rejoiced at everything that could be produced. The production was the defining party in the relationship with the consumer. Today, the market is considered to be the driving force behind the development of production. The initiative belongs to the buyer on the market. Transition to the principle: "The buyer is always right!" Involves determining the quality of the goods by its consumer.

The economic dominant in the characteristic of the quality of goods is clearly not up-to-date in the philosophical sense, but it expresses the essence of the bourgeois foundation of the existing economy, therefore, it will be defended politically and ideologically. Moreover, in a certain sense, it is interesting, in particular, to solve the problem of mobilizing the production potential for obtaining a demanded product in significant quantities, although the very quality of such a commodity will be conditional, "economic." The concept of "economy class" in the development of the notion "produced for sale in Russia" has been officially recognized.

We have already stressed that for 130 years bourgeois economists have been creating models for the effective production of high-quality goods in demand by the market, emphasizing the economic content of quality. Having driven the production movement to a standstill by economic models of quality, top managers, along with economists who isolated their profile of scientific interest from the socio-cultural goals of producing material goods, were forced to recognize the consumer not as a market anti entity but as a partner, an accomplice in the production process.

Recognizing the consumer as an ally is tantamount to including him in the production policy development team, albeit formally, because he remains in the previous position of the counterparty. In order to change the understanding of quality, it is necessary to start improving the production with the interests of the consumer, reflecting them in the properties of the goods, and then thinking about how to optimize the organization of its mass production. 


\begin{tabular}{|c|c|c|c|c|c|c|}
\hline \multirow{4}{*}{ Impact Factor: } & ISRA (India) & $=3.117$ & SIS (USA) & $=0.912$ & ICV (Poland) & $=6.630$ \\
\hline & ISI (Dubai, UAE & $=0.829$ & РИНЦ (Russia) & $=0.156$ & PIF (India) & $=1.940$ \\
\hline & GIF (Australia) & $=0.564$ & ESJI (KZ) & $=\mathbf{5 . 0 1 5}$ & IBI (India) & $=4.260$ \\
\hline & JIF & $=1.500$ & SJIF (Morocco) & $=5.667$ & & \\
\hline
\end{tabular}

Ultimately, at the outset, a compromise solution, justified by the possibilities of production and the need to move by expanding these possibilities, is also acceptable. Now the buyer basically remains a slave with the producer - the master and the political protectorate of the interests of big capital. The interests of the mass consumer are promoted by the gait of Japanese women, while the dominance in the production of the interests of enterprises is moved by the victorious parade. The pace of the movement is not comparable, there is no noticeable advantage in promoting the interests of the consumer and is not yet expected.

The consumer with his interest as a good is theoretically not excluded from the development of strategy, tactics and advertising. We refer to B.S. Aleshina and co-authors: "In order for the quality strategy to be successful, both the internal and external consumers should not only be satisfied and involved in the process providing this satisfaction, but also take a direct part in the continuous improvement of the quality of this process." To this end, the Kaizyo system was improved ; replacing it with a new edition of Kaizen. Changes in the organization of quality management have revealed the advantages of those countries where the mass consumer - he and the worker of production feels more comfortable, feels his complicity in the development of production. In the second half of the 1980s, Japanese enterprises received 40 times (!) More proposals to improve the production process from their employees than the US enterprises (40 million against 1 million). It is also significant that more than 90 percent of the proposals, in one way or another, were used. [4]

The ideology of quality is rebuilt into a new one - the consumer orientation is extremely reluctant and half-hearted. The quality management system ISO 9000 (in the Russian Federation - GOST R ISO 9000-2015) was introduced into the world practice 30 years ago. Its starting position (№ 1): "Product quality is a characteristic managed object", sets the general direction in the understanding of quality. Quality is a product of production. In point №2, the places of participants that affect the quality of the goods are specified: "the purpose of quality management is the creation of products of a quality level that meets certain, established requirements, needs." To make it clear about whose requirements and needs are being discussed, at the end of the paragraph we read through the comma - "customer requests".

The interests of the consumer are taken into account, but according to the residual principle. They are remembered last of all, "if the reserves of production permit." In scientific and popular sources, one can find an explanation for such a distribution of interests - technically complex products and their improvement is the lot of specialists. It seems that specialists are not consumers.

In ISO 9000 - 2015 for the first time at the very top of the list there is a consumer. The first principle of the QMS states: "Focus on the consumer." It is the consumer who declares quality properties. The status of the enterprise depends on how much the quality of the offered goods satisfies the requests to the quality of the buyers. The enterprise must understand their current and future needs, fulfill their requirements and strive to exceed their expectations.

But one should not rush to rejoice at the changes that have occurred. The quality management mechanism is still tuned to develop the quality of production technology, and not to obtain a quality product. The quality of the enterprise's activities is, as before, tested for maintaining the quality of production organization. Consumer interests remain "for later". All leading international quality management quality registrars are represented in Russia: Veritas, British Standards Institute, Lloyd's Registrar, Supervisory Society (TUV). In addition to them, numerous home-grown and joint ventures related to the certification of quality of production and products offer their services in the quality management market. The problem is not to find the desired organization, but that they are all "grounded" on production or the product out of context with the interests of consumers, which are quite specific and far from all in agreement with the views on the quality of producers.

The dialectics of the market uniting the producer and the consumer is simple - they are opposites that exist exclusively in unity, so we need to seek a balance of interests of both actors in order to give the production of quality goods a sustainable character that serves as protection against recessions and crises. Crises of overproduction - classical for capitalism of the XIX and the first half of the XX centuries became history. They were replaced by financial system shocks. Specialists are looking for a panacea in a qualitative, intelligent, efficient, lean production economy. "Historical experience shows that with the increasing attention to quality, the way out of crisis situations began in many countries. With the help of public policies aimed at improving quality, large-scale crises were overcome in Japan and Germany in the late 1940s. The crisis situations in the markets of the USA and Europe that arose in the late 1980s and early 1990s forced not only individual corporations but entire countries Sweden, the United Kingdom and the United States to pay attention to improving quality as the only means to help the national economy to withstand the onslaught of competitors "[5]

In solidarity with the above analysis of the economic history of the second half of the XX - first two decades of the 21 st century, we express surprise on ourselves, as it happened that in defining the 


\begin{tabular}{|c|c|c|c|c|c|c|}
\hline \multirow{4}{*}{ Impact Factor: } & ISRA (India) & $=3.117$ & SIS (USA) & $=0.912$ & ICV (Poland) & $=6.630$ \\
\hline & ISI (Dubai, UAE & $=0.829$ & РИНЦ (Russia) & $=0.156$ & PIF (India) & $=1.940$ \\
\hline & GIF (Australia) & $=0.564$ & ESJI (KZ) & $=5.015$ & IBI (India) & $=4.260$ \\
\hline & JIF & -1500 & SUF Mor & & & \\
\hline
\end{tabular}

newest social development through quality, the approach to understanding quality was not radically modernized. The totality of the quality value implies a revision of the content of the concept of "quality" and a new look at the factors that ensure the actual quality of the activity and its product. The systemforming position of the quality factor in social progress also determines a new political attitude to quality. The orientation of the development of production to internal ones is not required-not introduced messages.

Quality management must come from the need. It is in it, and not in rewarding for quality work in the form of incentives, the true beginning of a new economic policy. Encouraging, of course, no one is going to cancel, they are changed in places with motivation. Today, encouragement leads to the required quality of action, tomorrow the culture of professional attitudes toward work will be completed with incentives. Movement is most productive in the form of self-movement. External motivation is less effective. The remuneration should correspond to the quality of labor and to motivate labor sustainably.

The change in the qualitative strategy of economic policy from the incentive to quality production to the formation of the need for a quality product is not another attempt to revive economic romanticism and not communist nostalgia for the needs of the cultural person in labor as it may seem to those specialists who have restructured from political economy to economics, reducing the dialectical analysis to statistical, adapted to the volatility of modern production. It is a question of solving the system-forming problem of history - the relation of the individual to society and society to the individual, whichever side of this contradiction is more appealing, but in principle this is just a double spiral of social progress. A developed society is tested as a condition for the development of the individual. In its turn, a developed society is the very product of a person's cultural activity.

The formal and logical conclusion from the interdependence of the individual and society is obvious: it is necessary to build their relations in harmony, on the basis of awareness of mutual interest, bringing the interests to the degree of naturally needed needs (according to Epicurus classification) in each other. Now we are experiencing the historical stage of formal and abstract awareness of the basic contradiction of development by the individual and the subjects that determine politics. Personality and society, as it were, get used to the movement, looking for points of mutual growth. Partly successfully, there are many examples: mass production, freedom of access to education, sources of cultural development, political democracy, promotion of the nature management culture, solidarity in confrontation with extremist aspirations, joint use of scientific and technical achievements, strengthening of the authority of the idea of tolerance.

A special place in this list should be the desire for a quality economy. The point here is this: opposites, by definition, are mutually alienated. Dialectical opposites, to which the personality and society belong, are advantageous in that unity in their relations is inherent in the occurrence. It only needs to be brought to the general position by climbing from the formally necessary stage to the absolutely necessary, loading the process with real content, demonstrating in detail the benefits of interaction. There is no other way of overcoming, objectively laid in the relations between the opposites of the individual and society, alienation. Through the quality of the activity - to the quality of social improvement. It is unnatural to alienate what serves as a real condition for your development. Under the conditions of classical capitalism, alienation was a prerequisite for achieving the power of capital, and the very political organization of society adapted itself frankly to the provision of a bourgeois state. Democracy was adapted to the bourgeois social order.

The revolution of 1917 in Russia and the subsequent history of the USSR should be assessed not so much as national achievements, but rather as a turning point in the history of classical capitalism, a transition to the post-classical one. The dominance of private property and the advantages of capital remained untouched, but significant changes took place in the social superstructure. Class antagonism gave way to social partnership. Access to capital has led to the emergence of various forms of associative use of it in production. Cultural progress was accompanied by an interest in the quality of life, a change in the very concept. World cataclysms, of course, not just scared the people of Europe, Asia. They pushed the consciousness away from the abyss of extreme interests in solving contradictions.

The alienation of the individual in labor has not been overcome, but development has been objectively (society) and subjectively (personality) through mutual interaction. There are certain conditions for the removal of alienation. And the new approach to quality - consumer-production - is a milestone on the way of convergence of the main subjects of public life. He will force to make adjustments to economic policy, restore systemic understanding of society, limiting the desire to disintegrate public life "on the shelves."

The qualitative vector of the development of the economy, of course, will require additional costs, but for that the state with its economic instruments to try to compensate them. And the market is likely to react positively to a quality product by its activity.

In our view, the very existence of private property in the variety of forms of its realization is not a sufficient basis for alienation in the work of the 


\begin{tabular}{|c|c|c|c|c|c|c|}
\hline \multirow{4}{*}{ Impact Factor: } & ISRA (India) & $=3.117$ & SIS (USA) & $=0.912$ & ICV (Poland) & $=6.630$ \\
\hline & ISI (Dubai, UAE & $=0.829$ & РИНЦ (Russia) & $=0.156$ & PIF (India) & $=1.940$ \\
\hline & GIF (Australia) & $=0.564$ & ESJI (KZ) & $=5.015$ & IBI (India) & $=4.260$ \\
\hline & JIF & $=1.500$ & SJIF (Morocco) & $=5.667$ & & \\
\hline
\end{tabular}

individual. K. Marx, developing the idea of the alienation of G. Hegel, apparently had in mind a certain way of organizing labor, connected with the absolutization of the domination of private property. Private property serves as a potential economic basis for exploitation. But exploitation is not an inherent feature of it. One private property for exploitation is clearly not enough. As for the opposite private property of the public (public), which is governed by the state and serves as a real subject of property, it does not contain economic guarantees for overcoming alienation, which is not difficult to ascertain from the experience of the activities of domestic state monopolists.

It seems that the economic grounds for alienation should be sought not in ownership, but in distribution. Economic contradictions are insurmountable, but they allow management, the task of which is to control the nature of contradictions, to keep them within the limits of unimportant, acceptable differences that do not experience the existing unity of production for historical expediency.

To the point of recalling another observation of G. Hegel, recognized by F. Engels as the most important in understanding the dialectic of development: "Everything reasonable is real, everything is real reasonable". G. Hegel was able to discover the reasons for the need for systemic transformation of social relations, including economic ones.

In development there are two states that are perceived in the form of existence, but differ within the general status of their manifestation - "real existence" - "reality" and "real existence" - "reality." These forms of existence are fundamentally different on the basis. "Really existing" relies on the need to be in its form, it represents a developing reality. "Really existing" passed the stage of its necessity, ceased to be a factor of development, lost its relevance. It hinders the development process. Since the development of thinking and society Hegel understood in the form of a movement towards absolute rationality, he identified the necessity of the real with reality.

It is possible, of course, to squeeze out from the developed assortment and the established production technology to the last ruble. Question: Do I need to do this? Time moves forward in a certain mode, "in its own way," an objectively tailored "timetable." You will not get into the rhythm, you'll fall behind, you will stop meeting the changed requirements. The art of management - the management of production is not an exception, consists in the ability not to "fall out" of modernity, then you will always do this, in accordance with reason. Reasonable protection from most problems. "Demig's Seven Deadly Diseases" fit into one - do not fall out with the definition of the goods and the organization of production from the time cycle.

Only those who are able to mobilize human capital are able to do this, to properly concentrate financial and technical resources on this task. Without the ability to control the "pulse" of time - to understand the specific economic and socio-cultural situation, the state of consumer interests, the real possibilities of production, to find stability in the situation in the face of increasing competition in the market there is no chance. We will make one more addition - to a qualitative orientation of the development of production and the general conclusion becomes clear: the path of economic reasonableness lies through the creation of actual conditions for the formation of demand for quality products. Testing this need should be a responsibility to the consumer as to himself. The ancient wisdom of Confucius: Treat others as you would like them to treat you, not obsolete, on the contrary, following it provided advantages in the economic progress of the countries of Asia.

The specificity of achieving reasonableness in modern qualitatively oriented production is in the solidarity of human capital:

- the internal solidarity of producers, their need for quality;

- external solidarity with the consumer, consideration of the interests of the latter;

- solidarity in the understanding of quality on the basis of a combination of economic and sociocultural approaches;

- consistency and weightiness of the state's economic policy in terms of market orientation, inducing quality interests in market development with the tools of the economic mechanism. We tried to identify and summarize the basic conditions for achieving solidarity. To the extent that analysis of literary data allows us, this is done for the first time, therefore, clarifications and additions will be perceived positively. [6]

So, what should be considered as necessary conditions to achieve a radical change in the quality of production of a really good product - the transition from the stage of external audit to the stage of internal guarantee, formed by the formation of the need to create goods, the required quality of the consumer.

1. The presence of competition in the market of quality professional work, so that there is a clear understanding of the need to work in accordance with the needs of the commodity market. In another way, the market will not allow us to take a stable place on it.

2. Significant increase in purchasing power. Achieving the level that allows you to choose the right product. A quality product can not by definition be cheap, but it can be made available through market mechanisms. 


\begin{tabular}{|c|c|c|c|c|c|c|}
\hline \multirow{4}{*}{ Impact Factor: } & ISRA (India) & $=3.117$ & SIS (USA) & $=0.912$ & ICV (Poland) & $=6.630$ \\
\hline & ISI (Dubai, UAE & $=0.829$ & РИНЦ (Russia) & $=0.156$ & PIF (India) & $=1.940$ \\
\hline & GIF (Australia) & $=0.564$ & ESJI (KZ) & $=5.015$ & IBI (India) & $=4.260$ \\
\hline & JIF & $=1.500$ & SJIF (Morocco) & $=5.667$ & & \\
\hline
\end{tabular}

3. High level of professional training of producers, provided on the basis of the formation of professional culture and national identity. The main thing should be the upbringing of the attitude to work as a business that has dedicated its life. Expanded education of consumers, their perception as subjects of the common cause.

4. Overcoming the sensation of conscious and unconscious alienation of a person's ability in work and his products with the help of the following tools:

4.1. Achievement of symmetry in the quality of labor and remuneration.

4.2. Reduction to a reasonable correlation of differences in the remuneration of executives and executors, understandability of the bases in such proportionality.

4.3. Dependence of remuneration on the dynamics of further training and participation in the improvement of the production process.

4.4. The utmost use of socio-cultural mechanisms to stimulate the individual to the corporate movement, entry into command forms of the movement.

4.5. Sustainability of corporate activities.

4.6. Formation of relations by type: "One for all, all for one." Active promotion of the team form of responsibility for the results of work.

4.7. Organization of systematic competition in the quality of work.

4.8. Striving for national and international recognition of the quality and range of products produced.

4.9. Formation of labor dynasties, participation in the distribution of profits.

4.10. Understanding the quality of the product as an integrated product evaluation.

4.11. Awareness of the fact that it is "trifles" that reveal the perfection of quality, therefore, to trifles need to be treated as a building material of quality.

\section{Conclusion}

The internal life of an enterprise consists of a large number of different actions, subprocesses and processes. Depending on the type of enterprise, its size and type of activity, certain processes and actions may occupy a leading place in it, while others, processes that are widely implemented in other enterprises, may either be absent or be carried out in a very small amount. However, despite a huge variety of actions and processes, it is possible to distinguish five groups of functional processes that cover the activities of any enterprise and which are subject to management by management. These functional groups of processes are the following products: marketing, finance; work with personnel, accounting (accounting and analysis of economic activities).

Production management assumes that the relevant management services manage the process of processing raw materials, materials and semifinished products entering the enterprise into a product that the company offers to the external environment. To do this, the management performs the following operations: management of product development and design, selection of the process, placement of personnel and process equipment to optimize the costs of manufacturing and choosing methods for manufacturing the product, management of the purchase of raw materials, materials and semifinished products, inventory management in warehouses, including self-management of the storage of purchased goods, semi-finished products of own production for internal use and final products; quality control.

Marketing management is called through marketing activities for the implementation of the product created by the enterprise to link the satisfaction of the needs of the enterprise's customers and the achievement of the enterprise's goals in a single consistent process. To do this, it manages such processes and actions as: market research; advertising; pricing; creation of sales systems; distribution of products; marketing.

\section{References:}

1. Engels, F. (1961). Anti-Dühring. K. Marx and F. Engels. CIT., Ed. watt. M.: Gospolitizdat. t 20. p. 5-342, p. 827.

2. (2014). The big book of Eastern wisdom. (p.800, p.410). Moscow: Eksmo.

3. Hegel, G. (1975) Encyclopedia of the philosophical Sciences 1. Science of logic. (p.452, pp.341-342). M.:Mysl.
4. Aleshin, B. S. (n.d.). Philosophy and social aspects of quality: Ouch. POS. (p.238, p.103). M.: Logos.

5. (2000). Quality management. Vol. 2 Principles and techniques of total quality management. Fundamentals of quality assurance. (p.387). Moscow: mgiem. 


\begin{tabular}{|c|c|c|c|c|c|c|}
\hline \multirow{4}{*}{ Impact Factor: } & ISRA (India) & $=3.117$ & SIS (USA) & $=0.912$ & ICV (Poland) & $=6.630$ \\
\hline & ISI (Dubai, UAE & $=0.829$ & РИНЦ (Russia) & $=0.156$ & PIF (India) & $=1.940$ \\
\hline & GIF (Australia) & $=0.564$ & ESJI (KZ) & $=\mathbf{5 . 0 1 5}$ & IBI (India) & $=4.260$ \\
\hline & JIF & $=1.500$ & SJIF (Morocco) & $=5.667$ & & \\
\hline
\end{tabular}

6. (1955). The Materialists Of Ancient Greece. (p.238, p.210). M.: GOS. ed. polit. 1-R.

7. Prokhorov, V. T., et al. (2012). Managing production of competitive products in demand. Under the General editorship of doctor of technical Sciences, Professor V. T. Prokhorov (Eds.). (p.280). Novocherkassk: yurgtu (NPI).

8. Prokhorov, V. T., et al. (2014). The quality revolution: through the ad or through a quality real. Monograph; under the General editorship of doctor of technical Sciences, Professor V. T.
Prokhorov; VoIP (branch) of DSTU. (p.384). Novocherkassk: URGU (NPI).

9. Biryukov, A. N., Borilo, E. V., Glushchenko, O. I., \& Aspen, T. M. (2014). The regional economy: development trends. The monograph. (p.159). Voronezh : vgpu.

10. Reva, D. V., Korablina, Y. S., Prokhorov, V. T., Narozhnaya, I. G., \& Tikhonov, N. (n.d.). Formation of import-substituting assortment of shoes for domestic markets. pp.364-371. 